Vol. 6(6), pp. 117-121, J uly 2014

DOI: $10.5897 /$ JAR2012.041

Artic le Number: $09443 C$ D46283

ISSN 2141-2359

Copyright (c) 2014

Author(s) retain the copyright of this a ricle

http://www.academicjoumals.org/J AHR

\title{
Preliminary statement of HIVIAIDS conceptions among students at Abomey-Calavi (Benin) campus
}

\author{
Victorien Tamègnon Dougnon ${ }^{1 *}$, Clément Ahoussinou ${ }^{2}$, Roch Houngnihin ${ }^{3}$, Septime \\ Hessouh $^{2}$, Martin Aïna ${ }^{1}$ and Frédéric Loko ${ }^{1}$ \\ ${ }^{1}$ University of Abomey-Calavi (UAC), Polytechnic School of Abomey-Calavi, Cotonou, Benin. \\ ${ }^{2}$ Ministry of Health, National Program of Fighting against AIDS, Akpakpa, Benin. \\ ${ }^{3}$ Ministry of Health, National Program of the Pharmacopoeia and Traditional Medicine, Akpakpa, Benin.
}

Received 19 June, 2012; Accepted 2 July, 2014

\begin{abstract}
This study conducted at the campus of Abomey-Calavi in December 2009 evaluated students conceptions in relation to the theme of human immunodeficiency virus/acquired immune deficiency syndrome (HIVIAIDS). A target population of students was approached through a questionnaire. This descriptive study showed that $45 \%$ of the students were not satisfied with the level of fighting against AIDS in Calavi campus. $\mathbf{8 1 . 8 1 \%}$ of the students have already completed at least once time their HIV test. However, only $33 \%$ of them are aware of the figures of the real situation of HIV-AIDS in the student environment. $42.43 \%$ of the students were already sexually active and only $42 \%$ of them make systematic use of condoms with their partners. $48.48 \%$ of the studied population doubt the effective protection offered by condoms with HIVIAIDS, but $93.93 \%$ of them are aware of the actual existence of evil in the student environment. $60.60 \%$ of the target studies were between 20 and 25 years old. Nearly $90 \%$ of the students want the intensification of sensitization sessions in Calavi campus. This study provides an overview on knowledge about HIVIAIDS by students and could help to develop better strategies to fight the pandemic of the century among students. The student world is an important link in the fight against HIVIAIDS and greater attention should be paid to this layer.
\end{abstract}

Key words: Students, human immunodeficiency virus/acquired immune deficiency syndrome (HIVIAIDS), infection, condoms, test, Calavi campus.

\section{INTRODUCTION}

The sixth axis of the Millennium Development Goals (MDGs) known as "Stop the spread of human immunodeficiency virus/acquired immune deficiency syndrome (HIVIAIDS) by the year 2015" is dedicated to HIV infection, because of the size it takes and especially its socioeconomic impact (Primary Neurosurgical Life Support [PNLS], 2009). The future of humanity is dependent on the ability of men to fight effectively against the scourge of HIVIAIDS (Unité Focale de Lutte contre les IST/VIH/Sida, 2006). AIDS pandemic is now a concern of all humanity, because firstly, the extent of the damage it causes in terms of health and secondly, its negative impact on nations development. Despite efforts by the international community to curb the pandemic, infection

*Comespond ing author. E-mail: vic torien88@hotma il.com. Tel: 00 (229) 97736446.

Author(s) agree that this artic le rema in pemanently open access under the terms of the $\underline{C}$ reative Commons Attribution License 4.0 Intemational License 
continues to rise in the world in general and particularly in sub-Saharan Africa (Unité Focale de Lutte contre les IST/VIH/Sida, 2006). According to UNAIDS in 2005, more than 40 million people live with HIVIAIDS worldwide. Africa with $10 \%$ of the world population contains about $60 \%$ of people living with HIV which is 25.8 million in 2005 (Unité Focale de Lutte contre les IST/VIH/Sida, 2006)

It is no exaggeration to say that HIVIAIDS is a tragedy of modern times whose dimensions devastating in subSaharan Africa have significantly altered the socioeconomic parameters. This undermines efforts for decades, but also currently (Pisani, 2000; Schoof, 1999; UNAIDS, 2001). If epidemic obviously affects the growth of developing countries and increases poverty, its impact on education systems is even more devastating and farreaching long-term (Le Monde, 2002). In Benin, the situation is no less alarming. Indeed, since the first case of HIVIAIDS in 1985, we got to 8,196 cumulative cases of people living with HIV (PLHIV) in December 2005. Benin is a country in West Africa with about eight million people. As shown in Figure 1, the seroprevalence is relatively low, estimated between 1 and $1.3 \%$ for the whole country (United Nations Programme on HIV and AIDS [UNAIDS], 2010). Since 2006, HIV epidemic is stationary with a prevalence in Benin, which hovers around $1.8 \%$ with no significant difference between years (Figure 2). The epidemic is concentrated on specific groups called risk groups. The seroprevalence of HIV infection was $0.1 \%$ among pupils and students who are $2.1 \%$ of reported cases of AIDS. One of the patients of 10 is under 20 years old (Unité Focale de Lutte contre les IST/VIH/Sida, 2006). Despite notable efforts by various institutions in charge of the fight against this pandemic, there are few data on knowledge and attitudes of the student layer (Swain, 2005). Apart from the general literature on adolescents and HIVIAIDS, few studies placed particular emphasis on urban youth, social minorities, regarding their knowledge and behavior about HIVIAIDS (Thippeswamy and Gorvine, 2012). The figures are alarming, however, because it is estimated worldwide that six young people under 25 years are infected every minute (Yaro and Dougnon, 2003). Moreover, the proportion of subjects infected with HIV is significantly higher in urban areas: $2.7 \%(95 \% \mathrm{Cl}[2.54$ to 2.77$])$ than in rural areas $1.5 \%(95 \% \mathrm{Cl}$ [1.41 to 1.56$])$ (PNLS, 2009).

Indeed, the urban situation remains worrying. The prevalence is much higher than the national trend regardless of the year. It varies from 2.2 to $2.8 \%$ with a saw tooth development. Faced with this situation, the basic purpose of this study is to describe, understand and study the perceptions of a target population of young urban students made relative to the theme of HIVIAIDS. This study aims to provide descriptive information that could be used to monitor larger research projects. This would better tailor health education interventions with this population.

\section{MATERIALS AND METHODS}

\section{Framework}

This study was conducted at the Polytechnic School of AbomeyCalavi located at the University of Abomey-Calavi (UAC) in Benin. It took place on the occasion of World Day against AIDS of 1st December 2009. Questionnaires, a camera, ballpoint pens were used in this study.

This is a descriptive study that took place during an awareness session at Abomey-Calavi campus. Among the participants who were present, only thirty-three students have fully responded to the questionnaire. These thirty-three students aged from 20 to 25 years were invited to participate in data collection. Nine questions were administered to each student, after informed consent. The selected people were free to participate or not in the survey. After counting and coding, the questionnaires were numbered and archived. The data were entered into Epi-Data. A clearance program has corrected the inconsistencies and entry errors. Data were analyzed using Statistical Package for Social Sciences (SPSS) version 17.0.

\section{RESULTS AND DISCUSSION}

\section{Student satisfaction about the fight against AIDS}

Forty five percent of the study population is not satisfied. $55 \%$ of the students nonetheless feel that the struggle among students is good. Although more than half of those resources delivered a good mark at the fight, it remains true that $45 \%$ still have a contrary view. Indeed, nearly half of young the people questioned said that the fight among students should be reviewed. This could be due to the fact that the Abomey-Calavi campus has many associations fighting against the pandemic but unfortunately, this diversity in the student struggle that the funding is not coordinated. Thus, adverse effects were noted and nothing is done while everyone wants something to be done. Moreover, most of these organizations are much more interested in financial interests than the fight against the scourge, so they are not sustainable in general.

\section{Completion of testing by students}

On the implementation of the screening test, $81.81 \%$ of students have already done this test at least once in their life. This is probably due to free availability of this test in all the country's public courses. Moreover, the promiscuity of health centers and various audio-visual messages have certainly had a positive impact on the choice of these students to do their testing for HIVIAIDS. It is important to add to this free screenings organized by the national program of fighting against AIDS (Benin) in Calavi campus.

\section{Pandemic's numbers knowledge by students}

Thirty three percent of the students surveyed are aware 

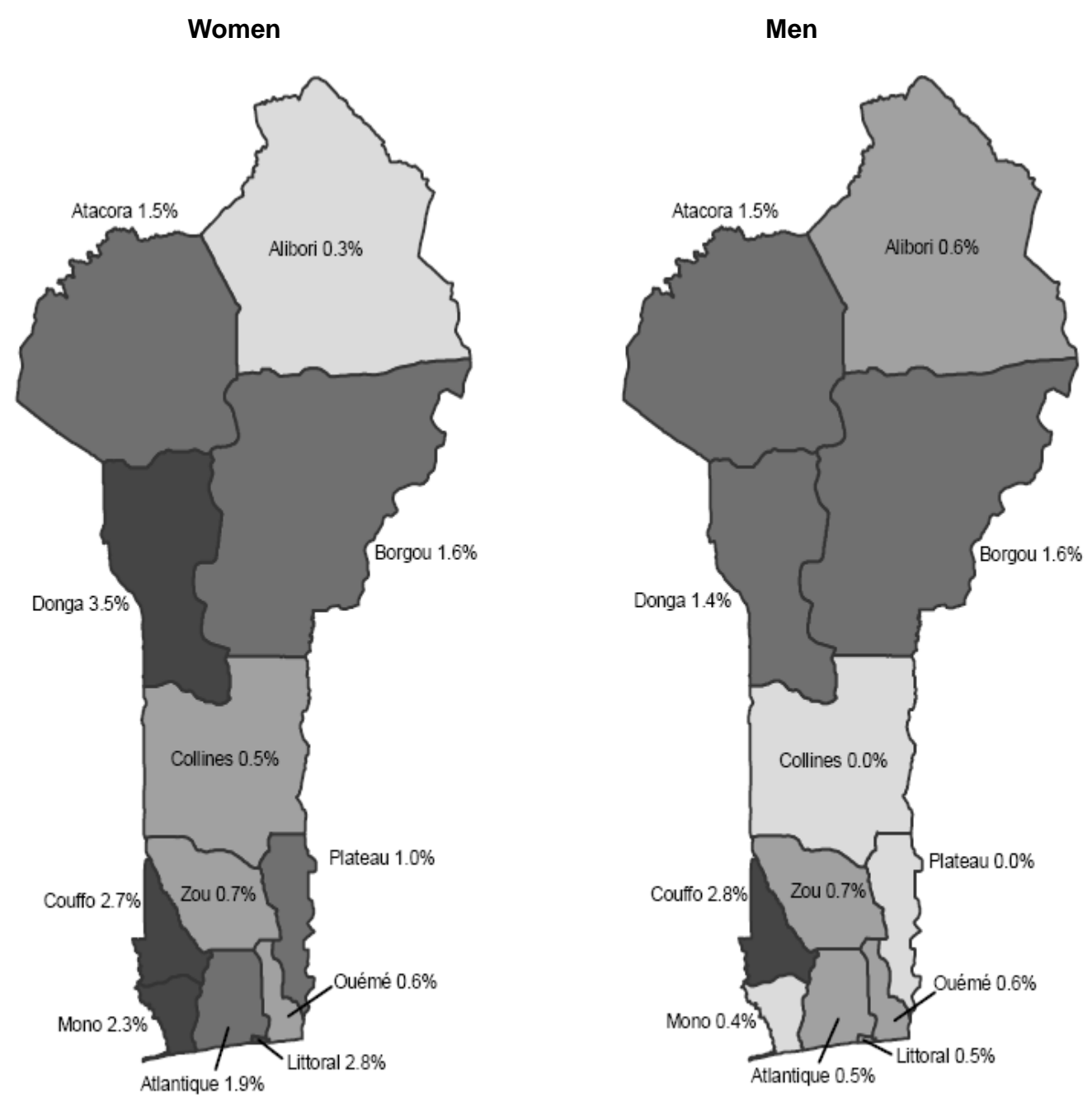

HIV prevalence

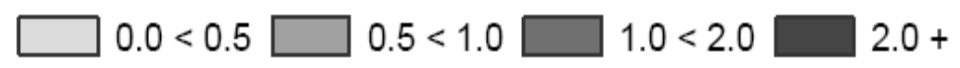

Figure 1. HIV prevalence in Benin estimated in 2006 by sex.

of the figures of the real situation of HIV-AIDS in the student environment. Indeed, very few students know the infection rate of young students by the AIDS virus, while many studies were conducted by the national program fighting against AIDS of Benin in 2008, 2009, 2010, 2011, and 2012. This situation shows that the release of the results of these studies should be stronger among the students. Integration of the theme of HIVIAIDS in education programs at the university would probably correct this situation. These results are confirmed by the work of Karfo et al. (2010) which showed that the limited knowledge of the students on sexual risk behavior was related to the fact that AIDS is not sufficiently taken into account in programs of secondary and higher education in Burkina Faso.

\section{Sexual activity among students}

Forty two percent of students had at least one time sex intercourse. These results were in contrast with those of Karfo et al. (2010) who noticed that $72.80 \%$ of Burkinabe students said they had sex intercourse at least one time. They believed that Burkinabe students have a high sexual freedom. The significant difference between these data could be explained by the difference between the two studies. In fact, the study of Karfo et al. (2010) is more recent. Nevertheless, it should be noted that Benin students are more very young $(60.60 \%$ of the target study were between 20 and 25 years) and the study conditions often harsh impact on their sexual frenzy. Only four in ten use condoms consistently before sex. Karfo et al. (2010) 


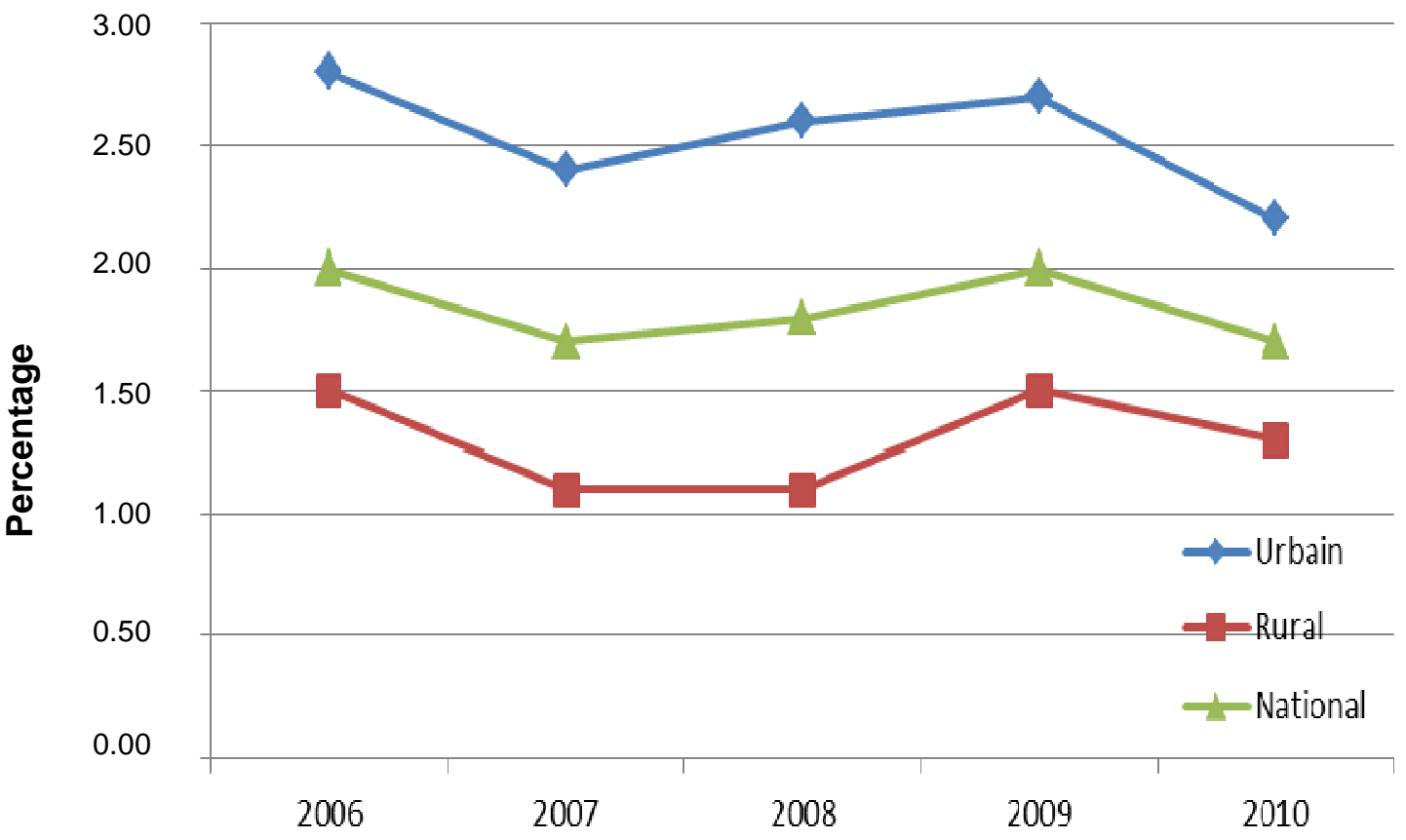

Figure 2. Trend of HIV infection in Benin from 2006 to 2010.

also found that nearly $34 \%$ of the Burkinabe students have had unprotected sex during their study. A U.S. study also found that few students used condoms.

The argument most often mentioned is that the condom dulls the sexual experience for both man and his partner (Thippeswamy and Gorvine, 2012). In Benin, many young people still continue to associate the use of condoms to "eat the banana with its skin." This shows that despite all the advice of the scientific community, condom use has still not taxed in the child layer. The limitation of sexual pleasure, the feeling of "eat banana skin" is a serious obstacle to this mode of protection, the condom.

$48.48 \%$ of students doubt the protection offered by condoms and HIVIAIDS, and this fully justifies the fact that they do not use them systematically. Many of students believe that condoms sometimes contain the AIDS virus and that is the cause of viral contamination. These unscientific designs show that serious efforts are still required to the awareness of young students.

\section{Notions of students in relation to HIVIAIDS}

Ninety three percent of the students are aware of the existence of effective HIVIAIDS in the student environment, despite the many risks they often adopt. Strunin (1991) noticed that African and American students were less knowledgeable than their white colleagues about the risks of HIVIAIDS, while being much more sexually active. This situation exposes them to more risks of disease transmission. Sikand et al. (1996), in a study on 771 students from New York, stressed that students have a fairly good knowledge of HIVIAIDS in general, but tend to engage in risky behaviors, despite what they know. This poses the problem of awareness. Would it not be preferable to mass sensitize individual approaches to targets, emphasizing the consequences associated with their actions? Trying to touch their conscience individually would certainly give better results.

Nearly $90 \%$ of the students want the intensification of sensitization sessions in Calavi campus which should no longer be done only during the world day of fighting against AIDS. It largely confirms the need of strategic actions for students in the Abomey-Calavi campus.

\section{Conclusion}

This study provides an overview in terms of knowledge about HIVIAIDS by students and could help to develop better strategies to fight the pandemic of the century among students. It is not an epidemiological study strictly but this was done to lead some decisions. University is a rich environment in pressure from all sides and a restructuring of the fight against the pandemic would be desirable. This is then an appeal to donors and strategic partners at various levels so that together the target zero can be made a reality.

\section{ACKNOWLEDGEMENT}

The authors are very grateful to the Project 
NUFFIC/NPT/151 at the Polytechnic School of AbomeyCalavi for all the dynamism in the fight against HIVIAIDS among students.

\section{Conflict of interest}

\section{Authors declare no conflict of interest.}

\section{REFERENCES}

Karfo K, Tiendrebeogo C, Ouango JG, Ouedraogo A (2010). Comportements sexuels à risque d'infection par le $\mathrm{VIH}$ chez les étudiants de l'université de Ouagadougou au Burkina Faso. Revue française de psychiatrie et de psychologie médicale, 14 (112) :22-26.

Le Monde (2002). Le sida tue l'Education en Afrique, Quotidien français. p.10.

Pisani E (2000). AIDS into the 21st Century: Some critical considerations. Reprod. Health Matters 8(15):63-76.

Primary Neurosurgical Life Support (PNLS) (2009). Annuaire des statistiques de l'année 2009 du Programme National de Lutte contre le Sida. République du Bénin. P 107.

Schoofs M (1999). The virus past and Future-AIDS the agony of Africa Part IV, Village Voice, New York. pp. 67-71.

Sikand A, Fisher M, Friedman B (1996). AIDS knowledge, concerns, and behavioral changes among inner-city high school students. J. Adolesc. Health 18(5):325-328.
Strunin L (1991). Adolescents' perceptions of risk for HIV infection: Implications for future research. Soc. Sci. Med. 32(2):221-228.

Swain KA (2005). Approaching the Quarter-Century Mark: AIDS Coverage and Research Decline as Infection Spreads. Crit. Stud. Mass Commun. 22(3):258-262.

Thippeswamy G, Gorvine B (2012). A qualitative assessment of HIVIAIDS-related knowledge in inner-city minority students. J. AIDS HIV Res. 4(3):85-93.

Unité Focale de Lutte Contre les IST/VIH/SIDA (UFLS) (2006). Politique de lutte contre le VIH/Sida et les IST en milieu scolaire. Rapport de politique stratégique, Bénin. p. 26.

United Nations Programme on HIV and AIDS (UNAIDS) (2001). AIDS 5 years since ICPD. Emerging issues and challenges for women, young people \& infants. UNAIDS discussion document. Geneva: UNAIDS. P 24.

United Nations Programme on HIV and AIDS (UNAIDS) (2010). Global Report - UNAIDS report on the global AIDS epidemic. $364 \mathrm{pp}$.

Yaro Y, Dougnon D (2003). L'impact du Sida sur l'offre et la demande scolaires en Afrique sub-saharienne. Rapport français pour la 36eme Session de la Commission de la Population et du Développement des Nations Unies, Centre Français pour la Population et le Dévelopement (CEPED), Ministère Français des Affaires Etrangères. $20 \mathrm{pp}$. 